\section{Ladan Hassani ${ }^{1}$ \\ Ehsan Taati}

Article info:

Received 12.04.2019

Accepted 11.09.2019

UDC - 004.738.5

DOI - 10.24874/IJQR14.01-11

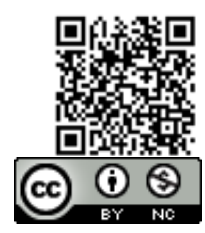

\title{
STUDYING PRODUCT QUALITY BY EXPLORING CREDIT CARD CUSTOMERS BEHAVIOUR VIA DATA MINING TECHNIQUES
}

Abstract: Recently, the competition has increased among Iranian-banks. This provides customer's satisfaction and quality-optimization. Nowadays, Credit-card is a new and significant product for Iranian-banks. Reports show customer's demand decreased by $21 \%$ in using credit-card in 2018. This study is aimed to identify high-quality customers of credit-card and develop the product quality through creating features in accordance with to their needs in order to increase customers' satisfaction. It was conducted on 1598 credit-card holders in two-phases. First, high-quality customers were selected using data-mining tools ( $K$ means/C\&RT algorithm); Results show 93 high-quality customers. Second, their data was studied the way of using credit-cards and its features from customers' perspective including how to pay installments, number of facilities documents, etc. Results show that $43 \%$ and $57 \%$ customers use the credit-card as a loan-card and revolving-credit respectively. Also, most customers of revolving-credit significantly consume allocated-credit in a transaction and start paying their debt in maximum-installments.

Keywords: Data-Mining; Credit-Card; Customer Satisfaction; K-means; Two-step.

\section{Introduction}

Providing quality services is one of the essential components for the success and survival of business enterprises in today's competitive environment. Quality in business literature has different meanings and can be examined in different aspects. From a manufacturer's point of view, the quality is the ability of a product to carry out the work on which it was designed. From a customer's point of view, the quality refers to those features of the product or service that affect the ability to create satisfaction (Ladhari, 2010). Kano, a renowned quality theorist, believes that today quality is an integral part of any business, and is one of the main factors in global competition. He believes that due to the growing global competition, it is not possible to meet customer needs only through current products, but new products must be constructed to meet his/her expectations, this depends on an accurate understanding of the needs and requirements of customer. Therefore, he defines quality as "to meet the needs and expectations of a customer, and, even, going beyond his satisfaction" (Valdés et al., 2011).

Therefore, in order to achieve acceptable quality in products/services, customer expectations and needs must be considered

\footnotetext{
${ }^{1}$ Corresponding author: Ladan Hassani Email:1.time.h5@gmail.com
} 
for the products/services provided and their perception of the products/services that they have actually received. However, on many occasions, customer service needs are not taken into account in the design of products/services. Researchers believe that delivering quality services to customers not only satisfies their current needs but also predicts future customer needs. The ability to predict future customer needs encourages customers to reuse their services and increase their level of satisfaction and loyalty to the organization. Therefore, each organization must try to improve its customer satisfaction by improving the quality of its products and services (Hua et al, 2011). Banks as a service provider are not exception.

In the last two decades, banking sector in developing countries has undergone regulatory changes that have led to increased competition among banks. Banks play a key role in financial market operations and maintaining the economy of a country. On the other hand, the quality of banking services is one of the essential elements for increasing customer satisfaction and loyalty and are important factors in improving the performance and success of banks and increasing their profitability and market share (Anabila \& Vitor, 2013). On the other hand, the highly competitive environment that banks have to work on, have made them to rethink their attitude and lead them to customer satisfaction and optimize service quality. Therefore, customer satisfaction is one of the key factors for business success in a competitive environment, and each organization strives to improve the quality of its products/services by providing customer satisfaction with a high level of achievement. The quality in services/products is only possible through the full recognition of the customer and the provision of products/services according to their needs. Credit-card is one of the new products that has been attracted the attention of Iranian banks in recent decade. Formal reports relating to credit-cards represent 21 percent decline in customer demand for using creditcard in 2018. Reducing the amount of creditcard usage indicates customer dissatisfaction. This problem is described further in the Problem Statement section.

\subsection{Problem Statement}

Credit card is one of the banking products that has been considered by Iran's banks for more than a decade. Promotion of this product due to its newness is possible through the improvement of the services quality related to this product. This requires improving the current features and creating new features tailored to customers' demands. Also, due to the limited resources of banks in the development of services quality related to credit-card, its profitability should be considered for the bank. To date, the features defined for a credit-card product have not been examined from the perspective of customers, in order to check its correspondence to their needs. Also the reports of credit-card in the bank in the last 3 years show that the number of demands of issuing credit-card in 2018 is less than that in 2016 (it has dropped 21\%). Also, compared with the number of transaction made by credit-card in 2016, it has decreased in 32\% in 2018. These results indicate that customers are not increasingly interested in using credit-cards. Table 1 shows the number of transactions and issued cards in studied bank in the last three years.

Table 1. Credit-card comparison over last three years

\begin{tabular}{|c|c|c|}
\hline Year & \multicolumn{2}{|c|}{ Variables } \\
\hline \multirow{2}{*}{2016} & Issued-card & 195,882 \\
\cline { 2 - 3 } & transaction & $1,978,633$ \\
\hline \multirow{2}{*}{2017} & Issued-card & 179,525 \\
\cline { 2 - 3 } & transaction & $1,622,479$ \\
\hline \multirow{2}{*}{2018} & Issued-card & 153,438 \\
\cline { 2 - 3 } & transaction & $1,345,470$ \\
\hline
\end{tabular}

So, it is necessary to study on credit card in order to enhance customers' satisfaction and their willingness to use credit cards. 
Also, the technology development has led to the accumulation of a large amount of data throughout the life-cycle of the product, including design, production, sales, and etc (He et al., 2016). The banking industry is no exception to this, and the expansion of ebanking has led to the recording of all customer data, including their transactions, which can be used to better understand the customers needs, allocate optimal resources to customers and boost bank productivity.

Data-mining is one of the successful tools used in various industries in designing products, supporting decisions, identifying customer behavior patterns, and etc (Xu et al., 2016). Data-mining is now becoming an important area for many industries, including the banking industry. This process analyzes data from different perspectives and ultimately summarizes it with meaningful information. This tool has various applications such as marketing and retail management, customer relationship management, market segmentation based on product and service, and etc in the banking industry (Farooqi \& Iqbal, 2017). According to the above, this study was aimed at identifying high-quality, loyal credit-card customers and developing the quality of this product through the creation of features tailored to their needs. So the credit-card customers of one of Iran's state-owned banks were surveyed.

In order to identify high-quality banking customers, a list of related indicators was first identified by studying the research literature and interviewing experts in the banking industry. By analyzing customer behavior patterns in order to increase bank revenues from credit-card based on identified indicators, customers were divided into high quality customers, average quality customers and low quality customers. Then, the high-quality credit-card customer's behaviors were explored on how to use credit-card features. Finally, based on the analysis done to increase the quality of the credit-card product, designing and creating new features or modifying the existing features were proposed. These steps are presented in Figure 1.

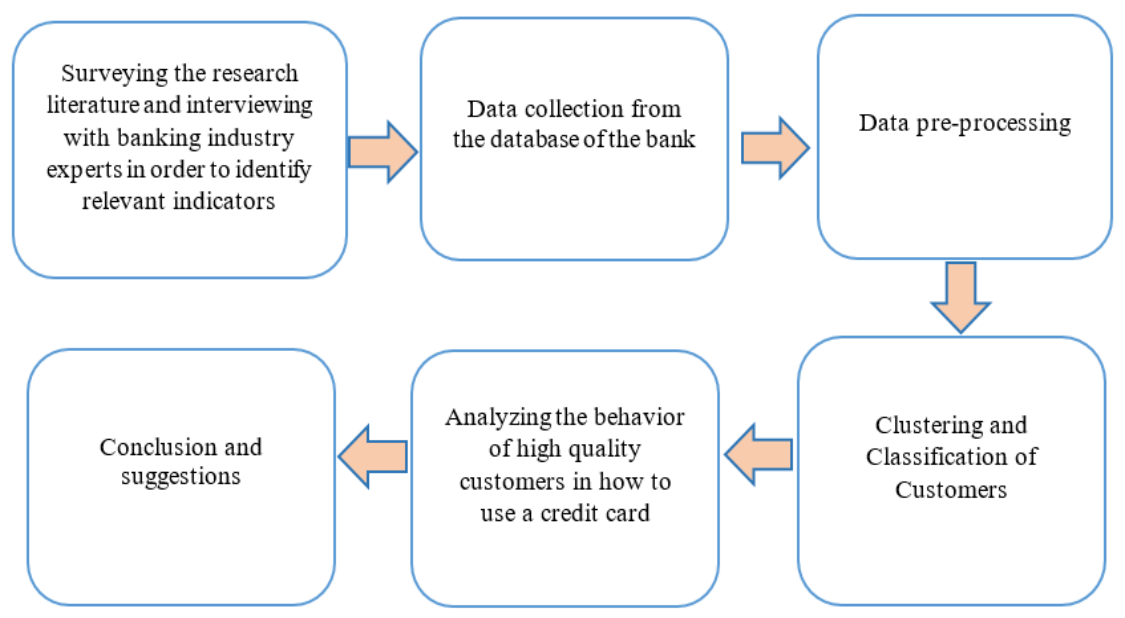

Figure 1. Research process

\section{Literature Review}

Considering the objectives of this research, this section examines the credit-card mechanism in Iran, studies on the provision of services in the banking industry focusing on the banking services quality and their relationship with customer satisfaction, also the data-mining application in identifying high-quality customers. 


\subsection{Credit Card in Iran}

A credit card is a bank instrument issued by banks to individuals or legal entities, and the terms and conditions for each party are specified under a contract between a bank and a customer. This tool allows the card holder to buy goods or services from the seller. (Al-Qudah et al., 2012) In Iran, this product was designed with the purpose of increasing purchasing power and in accordance with international standards based on the moratorium contract and nonusury banking law, with the exception that the use of these cards in Iran is merely limited to buying from shopping malls and stores (while it is possible to receive cash from ATMs and transfer credit balances to international credit cards). Currently, three types of moratorium credit cards with regard to its credit limit (including the credit limit of 100, 300 and 500 million-Rials) are issued, and their features are as follows:

1. Possibility of debt installment of purchase and flexibility in the method of credit-card repayment taking into account different time frames.

2. Possibility of using the credit card as a fixed (loan credit card) or revolving credit card.

\subsection{Credit card in other countries}

Credit cards are also developed for the convenience of paying customers in other countries and credit-card holders use these cards in shopping daily necessities or in buying cars and house. For international cards, the cardholder is allowed to withdraw and shop from his/her account up to the credit limit assigned by the bank. After using credit and elapsing a certain period and in order to pay the debt, bank sends them the customer's statement. Some banks even take this debt from their customers in installments. Therefore, the main features of this card in other countries include:
1. Withdrawal and purchase up to the credit limit assigned by the bank.

2. A possibility to divide debt due to purchase and flexibility in the way of credit card repayment. (Khansari, 2016)

\subsection{Services Quality}

A study was conducted with the aim at examineing the satisfaction and loyalty of bank customers regarding the quality of the various services offered by the Pakistani banks. In this research, the questionnaire was used to assess the services quality provided to customers and then to examine its relationship SERVQUAL with customer satisfaction and loyalty. Study findings confirmed a positive relationship between service quality and customer satisfaction (Munawar Khan \& Fasih, 2014). Also a study was conducted with the aim at evaluating the quality of perceived services provided by different Greek banks. The results showed that there was a significant difference between the perceived quality of banking services offered by different banks in Greece. Moreover, in this study, the relationship between customer service quality and customer loyalty was investigated, and the results confirmed a significant relationship between customer service quality and customer loyalty (Kraniasa et al., 2013). Another study investigated the relationship between the qualitative characteristics of Islamic banking products and customer satisfaction in Nigerian banks. Results showed a significant impact of the perceived quality of products on customer satisfaction. It was also found that there was a significant relationship between the cost of using products and the level of customer satisfaction, and customers tend to use less costly banking products (Baba et al., 2018). Also a study investigated the impact of service quality on customer loyalty and performance of Taiwan's financial institutions. Results showed that promoting the service quality could 
significantly influence the companies through the intermediary effect of customer loyalty (Liu \& Wang, 2017). Another study investigated the effect of customer satisfaction on improving the performance of Scandinavian banks. Its results showed a positive effect of customer satisfaction on the profitability and financial performance of the bank (Eklofa et al, 2018). Another study investigated the impact of service quality, innovation, and technology and staff commitment on the performance of banks in Malaysia. The findings showed that the performance of Malaysian banks was heavily influenced by technology and innovation in products and services (Boon-Hui Chai et al, 2016). Another study examined the impact of service quality on customer satisfaction in Greek banks and the service quality was measured from two different aspects, namely, the quality of performance (how the bank operates effectively) and the relationship (intimacy between customers and the bank and employees of the bank). The findings showed that the performance quality did not affect customer satisfaction, while communication quality positively affected customer satisfaction. (Keisidou et al, 2013).

\subsection{Customer Classification}

Of the major challenges in customer-based organizations are the recognition of the customer, an understanding of the difference between them and their ranking. Recently, customer value has been used as a measurable parameter for customer classification. Considering the importance of the issue, some research has been carried out in this area. A study presented a framework for classifying banking customers based on their value. So, customers' history in different periods was studied using K-Means and RFM techniques and their future behaviors was predicted (Khajvand \& Tarokh, 2011). A study was conducted with the aim at identifying clusters key customers in order to create more efficient strategies for them. In this research, customers' data were analyzed using two-step and RFM clustering methods. The findings showed the distinction between bank customers' clusters based on the amount of loans, predetermined risk, inventory, loyalty and profitability for the bank (Ansari \& Riasi, 2016). Another study was conducted with the aim at creating benefits to the bank such as attracting profitable customers, maximizing investment in sales and delivery channels, creating competitive advantage in the market, and improving their services to feature analysis. For this purpose, the investigated E-banking customers and their behavior by clustering methods of K-means and RFM. In this research, criteria such as access time, transaction and RFM, LTV and populationcognitive variables were investigated. (Kumar et al., 2012). Some of the studies used here are presented in Table 2.

Table 2. Litrerature Review

\begin{tabular}{|c|c|c|c|c|}
\hline \multicolumn{5}{|c|}{ DATA-MINING Techniques } \\
\hline No & Studies & Purposes and key findings & research design and analysis & limitations \\
\hline 1 & $\begin{array}{l}\text { (Doğan et al., } \\
\text { 2018) }\end{array}$ & $\begin{array}{l}\text {-Customer segmentation, } \\
\text { detecting similarities and } \\
\text { differences among } \\
\text { customers, predicting their } \\
\text { behaviors, proposing better } \\
\text { options and opportunities } \\
\text { to customers }\end{array}$ & $\begin{array}{l}\text {-K-means } \\
\text {-RFM technique }\end{array}$ & Not-mentioned \\
\hline 2 & $\begin{array}{l}\text { (Alborzi \& } \\
\text { Khanbabaei, } \\
\text { 2016) }\end{array}$ & $\begin{array}{l}\text {-Presenting a new hybrid } \\
\text { model for behavioral } \\
\text { scoring and credit scoring }\end{array}$ & $\begin{array}{l}\text {-Data-mining technique } \\
\text {-Neural networks } \\
\text {-WRFMLCs analysis method }\end{array}$ & Not-mentioned \\
\hline
\end{tabular}


Table 2. Litrerature Review (continued)

\begin{tabular}{|c|c|c|c|c|}
\hline 3 & $\begin{array}{l}\text { (Farokhi et al., } \\
\text { 2016) }\end{array}$ & \begin{tabular}{|l|}
-Using the information \\
gathered from Point of \\
Sales (POS) for \\
detecting the most \\
profitable customer \\
customers \\
-Customer segmentation
\end{tabular} & $\begin{array}{l}\text {-K-means } \\
\text {-Kohonen }\end{array}$ & Not-mentioned \\
\hline 4 & $\begin{array}{l}\text { (Fouladifar et } \\
\text { al., 2016) }\end{array}$ & $\begin{array}{l}\text {-Clustering e-banking } \\
\text { customers for enhancing } \\
\text { customer relationship and } \\
\text { developing services }\end{array}$ & $\begin{array}{l}\text {-K-means } \\
\text {-RFM technique }\end{array}$ & -accuracy \\
\hline 5 & $\begin{array}{l}\text { (Butaru et al., } \\
\text { 2015) }\end{array}$ & $\begin{array}{l}\text {-Risk and risk management } \\
\text { in the credit card Industry }\end{array}$ & \begin{tabular}{|l|}
-Decision-tree \\
-Regularized logistic \\
regression \\
-Random-forest models \\
\end{tabular} & Not- mentioned \\
\hline \multicolumn{5}{|c|}{ Quality \& Customer Satisfaction } \\
\hline No & Studies & Purposes and key findings & \begin{tabular}{|l} 
research design and \\
analysis
\end{tabular} & limitations \\
\hline 6 & $\begin{array}{l}\text { (Baba et al., } \\
\text { 2018) }\end{array}$ & $\begin{array}{l}\text {-Influencing of Islamic } \\
\text { bank's products quality } \\
\text { features on customer } \\
\text { satisfaction }\end{array}$ & $\begin{array}{l}\text {-Structural equation } \\
\text { model }\end{array}$ & Not-mentioned \\
\hline 7 & $\begin{array}{l}\text { (Liu \& Wang, } \\
\text { 2017) }\end{array}$ & $\begin{array}{l}\text {-Effecting of service } \\
\text { quality on customer loyalty } \\
\text { and corporate performance } \\
\text { in financial industry. }\end{array}$ & $\begin{array}{l}\text {-Multiple regression } \\
\text { analysis }\end{array}$ & Not-mentioned \\
\hline 8 & $\begin{array}{l}\text { (Boon-Hui Chai } \\
\text { et al., 2016) }\end{array}$ & $\begin{array}{l}\text {-Effecting of service } \\
\text { quality, innovation, } \\
\text { technology and employee } \\
\text { commitment on the bank } \\
\text { performance }\end{array}$ & $\begin{array}{l}\text {-Pearson correlation } \\
\text { analysis } \\
\text {-Multiple regressions } \\
\text { analysis }\end{array}$ & $\begin{array}{l}\text {-The result of this } \\
\text { research is merely based } \\
\text { on non-financial } \\
\text { indicator, the result does } \\
\text { not fully represent the } \\
\text { bank performance as it } \\
\text { would need both the } \\
\text { financial and non- } \\
\text { financial indicators to } \\
\text { give a better picture } \\
\text {-small sample size and } \\
\text { accuracy }\end{array}$ \\
\hline 9 & $\begin{array}{l}\text { (Chochol'áková } \\
\text { et al., 2015) }\end{array}$ & $\begin{array}{l}\text {-Examining and } \\
\text { quantifying the dependence } \\
\text { of additional purchases of } \\
\text { banking products from } \\
\text { customer loyalty and } \\
\text { dependence of bank } \\
\text { clients' loyalty from their } \\
\text { satisfaction with the bank's } \\
\text { customer service. }\end{array}$ & $\begin{array}{l}\text {-Pearson correlation } \\
\text { coefficient }\end{array}$ & Not-mentioned \\
\hline 10 & $\begin{array}{l}\text { (Garvey Orji et } \\
\text { al., 2017) }\end{array}$ & $\begin{array}{l}\text {-Assessing the impact of } \\
\text { new products development } \\
\text { on the profitability of } \\
\text { Nigerian deposit money } \\
\text { banks }\end{array}$ & -Kendall coefficient & $\begin{array}{l}\text {-Low response rate } \\
\text { which lessens the } \\
\text { generalisability of the } \\
\text { findings to the entire } \\
\text { population of Nigerian } \\
\text { banks }\end{array}$ \\
\hline
\end{tabular}


With regard to what has been learned from previous researches, all of these researches have addressed the customers' classification and the impact of service quality on customer satisfaction separately. However, in this study, the results of the classification will be used to analyze the existing features of the credit card and provide a solution to increase its quality and thereby increase customer satisfaction.

\section{Research Methodology}

According to the large number of data of credit card customers and extracting useful patterns and information from the customers' database, data-mining method including clustering and classification is applied to analyze data. There are several fields in which data-mining can be used in the banking industry. They include customer classification in terms of their productivity, prediction of debt payment, marketing, fraud transactions detection, fund management and prediction operation, treasury asset optimization and investment rank. In general, banks can use data-mining to identify productive customer of credit-cards and high-risk loan applicants. (LiébanaCabanillas et al, 2013) CRISP-DM and SEMM are methods of data-mining projects. In this study, CRISP-DM, a common datamining method, is used. The main purpose of selecting CRISP-DM in this study is to be more widely used than other methods also more understandable than others for users, according to research conducted by the Data-
Mining Research Association in 2007. This method consists of stages of business recognition, data perception, data preparation, modeling, evaluation and development. Therefore, after recognizing the business in the first stage, data on creditcard customers was collected from a database of one of the bank affiliated companies, whose field of work is "issuing and supporting credit-card". It should be noted that the data were extracted from the SQL database and then converted to an Excel format, and the Excel file was used for further analysis by Clementine software. Then the preprocessing data including data cleansing and converting were done. In the next step, to know more about the population, the clustering method was used. At this stage, demographic variables were separated from other variables. The reason for this separation is to eliminate the impact of customer demographic data on the clustering stage. In the modeling stage, the results obtained in the previous stage were used to classify customers into three classes of high quality, average quality and low quality customers and the rules were extracted. In the classification stage, the demographic data of customers were also added to other data. In the final stage, the results obtained from the previous step were reviewed to examine the features of the products and define the features that are tailored to the needs of high quality customers. Research conceptual model is shown in Figure 2.

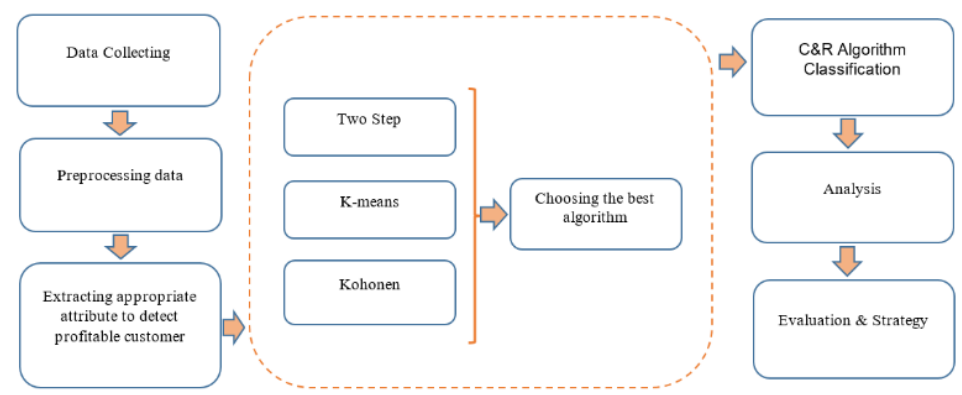

Figure 2. Conceptual Model 


\subsection{Sample Selection}

Given that the purpose of the study was to investigate the behavior of credit-card holders in debt installment, how to use a credit-card, and etc, the population of this study includes all credit-card holders. In the same way, a sample of 1598 persons who have been issued a credit-card account in an Iranian bank who had the credit file date in the period from 2016/08/22 to 2016/10/22 were randomly selected. This information includes items such as non-overdue debt, overdue-debt, allocated-credits, interest, number of loan files, consumed credit, monthly consumption, etc. After consulting with industry experts, some of them related to the subject of the research were selected.

\section{Results and Discussion}

\subsection{Descriptive Statistics}

As stated above, in order to reach the research purpose, 1598 people were selected. Table 3 describes the sample.

Table 3. Descriptive statistics

\begin{tabular}{|c|c|c|c|}
\hline \multicolumn{2}{|c|}{ Variables } & Frequency & Percent \\
\hline \multirow{4}{*}{ Gender } & Male & 1097 & 68.6 \\
\cline { 2 - 4 } & Female & 501 & 31.4 \\
\cline { 2 - 4 } & Sum & 1598 & $100 \%$ \\
\hline \multirow{4}{*}{$\begin{array}{c}\text { Age } \\
\text { (years old) }\end{array}$} & $20-30$ & 216 & 13.5 \\
\cline { 2 - 4 } & $30-40$ & 585 & 36.6 \\
\cline { 2 - 4 } & $40-50$ & 424 & 26.5 \\
\cline { 2 - 4 } & $50-60$ & 230 & 14.4 \\
\cline { 2 - 4 } & Older than 70 & 83 & 5.2 \\
\cline { 2 - 4 } & Sum & 60 & 3.8 \\
\hline \multirow{3}{*}{$\begin{array}{c}\text { Allocated-credits } \\
\text { (million rial) }\end{array}$} & 100 & 1598 & 39.5 \\
\cline { 2 - 4 } & 300 & 631 & 27.2 \\
\cline { 2 - 4 } & 500 & 434 & 33.4 \\
\cline { 2 - 4 } & Sum & 533 & $100 \%$ \\
\hline
\end{tabular}

\subsection{Data Preprocessing}

Data collected from the real world generally has problems such as noise, missing data, and data outside the acceptable range. If these data are used in data-mining before examination and preprocessing, they will not be able to provide acceptable results or create problems in the data-mining process. Therefore, data preprocessing is performed to prepare raw data. The steps for data preparation are described in Table 4.

Table 5 describes the operational definitions of some of the variables used in this research.

Table 4. Data preparation steps

\begin{tabular}{|c|l|l|}
\hline 1 & Removing duplicate data & $\begin{array}{l}\text { Finding and removing duplicate data from the data set by using the } \\
\text { remove duplicates tool in Excel software }\end{array}$ \\
\hline 2 & Creating new features & Converting and modifying variables and creating a new variable \\
\hline 3 & Discretization & Converting continuous variables to discrete variables \\
\hline 4 & Management Missing Value & $\begin{array}{l}\text { Finding Missing Values and Removing or Replacing them. In this } \\
\text { research, C\&RT algorithm was used to replace missing data. }\end{array}$ \\
\hline 5 & $\begin{array}{l}\text { Management Extreme and } \\
\text { Outlier }\end{array}$ & $\begin{array}{l}\text { At this point, the anomaly detection method was used to identify and } \\
\text { manage Extremes and Outliers. Difference between this method with } \\
\text { other methods is the multidimensional look at Extreme and Outliers } \\
\text { and to identify the values outside of the range in all variables. }\end{array}$ \\
\hline
\end{tabular}


Table 5. variables's operational definitions

\begin{tabular}{|c|l|l|}
\hline NO & Variable name & \multicolumn{1}{c|}{ Operational definition } \\
\hline 1 & Allocated-credits & $\begin{array}{l}\text { The maximum amount of credit the Iranian-Banks grants to the applicant } \\
\text { after validation. }\end{array}$ \\
\hline 2 & Credit file & $\begin{array}{l}\text { Includes all identity and customer debt information within a specified time } \\
\text { period. }\end{array}$ \\
\hline 3 & loan files & $\begin{array}{l}\text { Debt instrument include information on facilities created during the use of } \\
\text { credit-cards by the Card holder. In other words, each of the loan file } \\
\text { includes the total amount of purchases made during a one-month period. }\end{array}$ \\
\hline 4 & Customer status & $\begin{array}{l}\text { This variable shows the different statuses of each customer credit file. For } \\
\text { example, by paying the debt of credit-card, and at the request of the } \\
\text { customer, the credit file is closed. }\end{array}$ \\
\hline 5 & non-overdue debt & $\begin{array}{l}\text { If less than 2 months has passed after the customer's installment, his debt } \\
\text { will be called non-overdue debt. }\end{array}$ \\
\hline 6 & overdue debt & $\begin{array}{l}\text { If more than two months has passed after the customer's installment, his } \\
\text { debt will be transferred to the overdue debt class. }\end{array}$ \\
\hline
\end{tabular}

The titles and statistical data of the collected data from the database are shown in Figure 3 (see Appendix).

Figure 4 shows an overview of the preprocessed data used in the analysis (see Appendix).

According to industry experts, some variables including interest, annual percentage rate (APR) and customer debt, are not appropriate criteria for judgment and, depending on their nature, are dependent on allocated-credits and consumed Credit. In the initial analysis of the data and the clustering-stage, the above variables were used, but, for the customer classification, the indicators of "debt to consumed credit", "profit to consumed credit" and "APR to allocated-credits" were calculated and replaced the above mentioned variables.

\subsection{Clustering Stage}

We used clustering methods to identify the population. When there was not much knowledge of the data, different clusteringalgorithms can be used to identify different groups of the study population. The whole sample (1595) was examined before clustering. The average debt and InterestPaid before clustering were equal to $155,517,697$ and $61,474,581$ respectively. So the clustering-stage was done to select the group of key customers with the highest profitability and debt for the bank. At the clustering-stage, customers, in terms of profit, debt, allocated-credits, consumedcredit and APR, was examined. Different algorithms were used and the best algorithm was selected by comparing the algorithms of silhouette indices. (Rousseeuw, 1987) According to Figure 5, the Two-Step algorithm with 2 clusters had the highest silhouette, the results of which are described in more detail below.

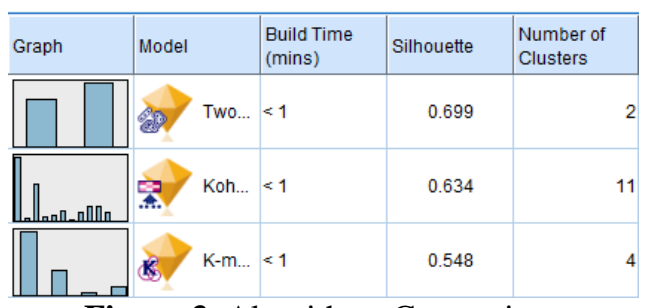

Figure 3. Algorithms Comparison

Figure 6 shows the results of the two-step algorithm. As you can see, the value of the silhouette of this algorithm is 0.7 and is acceptable. The data overview after the clustering is shown in Figure 6.

The variables were also considered regarding their importance, showing that the variables of allocated-credits, APR, and profit were more important than other variables (Figure 7). 


\begin{tabular}{|c|c|c|c|c|c|}
\hline & Debt & Interest paid & Annual Percentage Rate & Allocated credit & \begin{tabular}{|l|l|} 
Consumed credit & \$T-TwoStep 1
\end{tabular} \\
\hline 1 & $25599902.0 \ldots$ & $23383528 \ldots$. & 1000000.000 & 100000000.000 & 100000000.000 cluster- 1 \\
\hline 2 & 90222053.0.. & $24850640 \ldots$ & 1000000.000 & 100000000.000 & 300803409.000 cluster -1 \\
\hline 3 & 45957691.0. & $22464903 \ldots$ & 1000000.000 & 100000000.000 & 100000000.000 cluster- 1 \\
\hline 4 & $33113655.0 \ldots$ & $25558011 \ldots$ & 1000000.000 & 100000000.000 & 129288000.000 cluster- 1 \\
\hline 5 & 0.000 & $22731717 \ldots$ & 1000000.000 & 100000000.000 & 100000000.000 cluster- 1 \\
\hline 6 & 0.000 & $36291920 \ldots$ & 1000000.000 & 100000000.000 & 99878000.000 cluster- 1 \\
\hline 7 & 0.000 & $22395040 \ldots$ & 1000000.000 & 100000000.000 & 100000000.000 cluster- 1 \\
\hline 8 & 0.000 & $27731221 \ldots$ & 1000000.000 & 100000000.000 & 129440000.000 cluster- 1 \\
\hline 9 & $15364784.0 \ldots$ & $24520732 \ldots$ & 1000000.000 & 100000000.000 & 99994200.000 cluster-1 \\
\hline 10 & $42540246.0 \ldots$ & $21858195 \ldots .$. & 1000000.000 & 100000000.000 & 109260000.000 cluster- 1 \\
\hline
\end{tabular}

Figure 6. Data Overview after clustering
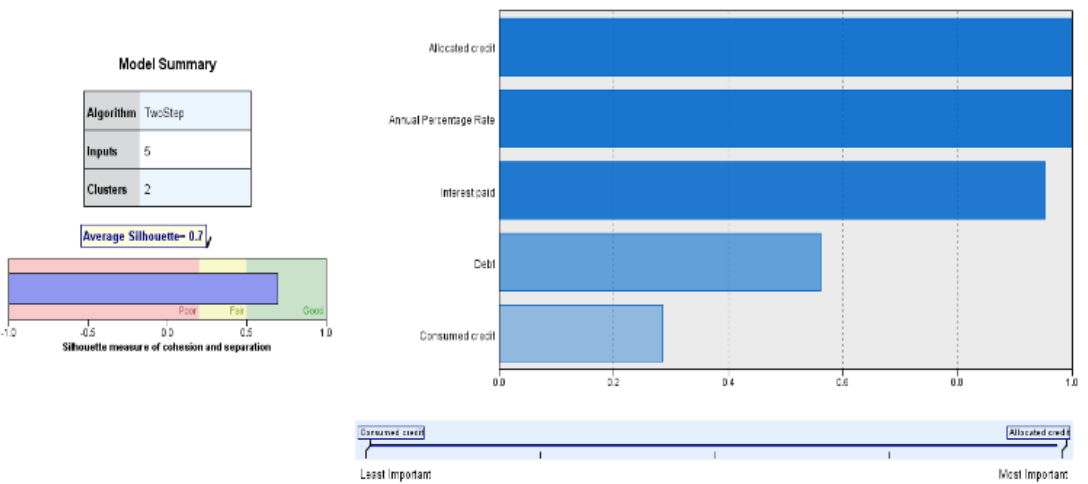

Figure 7. Variables Importance

The overview of each cluster and the Input (Predictor) Importance variables distribution in each cluster are shown in Figure 8.

As it is known, the largest number of customers is located in cluster2; also this cluster has a better distribution than cluster1. To further examine the data, the statistical characteristics of the two identified groups from the two-step algorithm were investigated, the results of which are shown in Table.6. According to the table, the average paid profit in cluster 1 and 2 were 24,008,731 and 98,940,431 millionRials, respectively, so, the customers of the cluster.2 had higher profit. Also the average debt in cluster 1 and 2 were 42,036,834 and 268,998,559 million-Rials, respectively, indicating that cluster.1 customers' debt level was less than cluster.2. Given that customers in cluster.2 had higher profitability and more debt than customers in cluster.1, they had a higher priority than cluster.1 customer one, so, the information about cluster.2 customers are used as inputs of the decision tree.

Figure 9 shows the clearing model and data clustering.

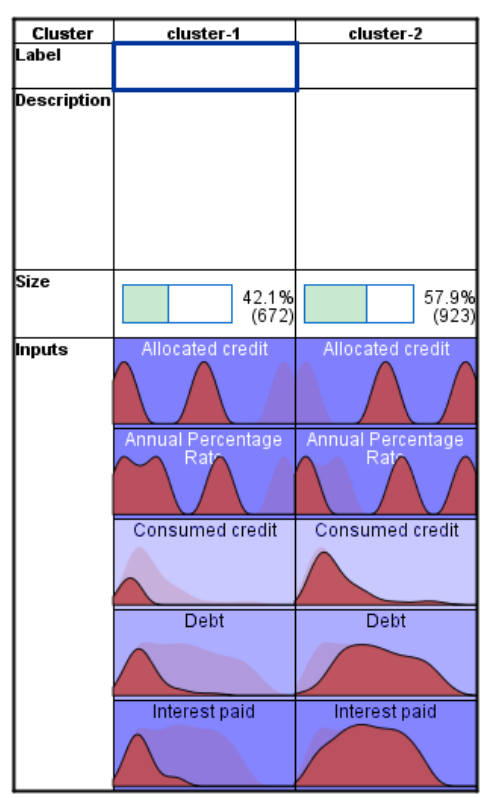

Figure 8. Clusters overview 
Table 6. Clusters Comparison

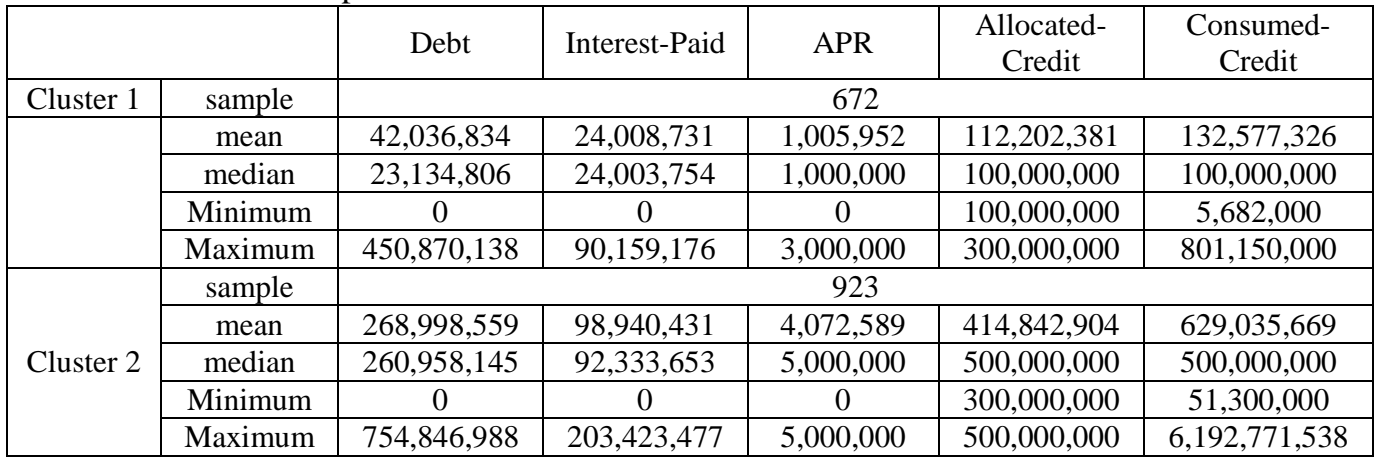

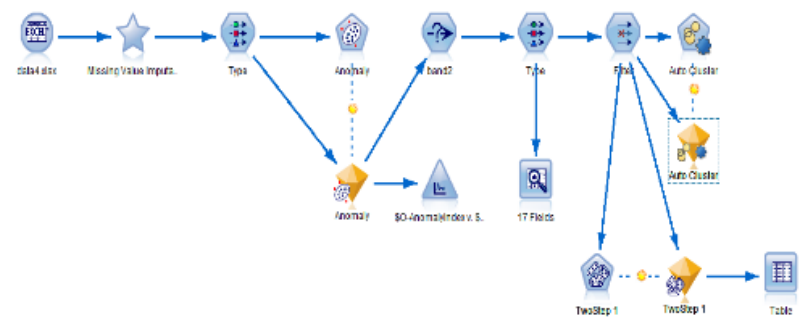

Figure 9. Model for preprocessing and clustering Stages

\subsection{Customers Classification}

At this stage, the data on cluster 2 were introduced into the model for classification. In this research, the C\&RT classification algorithm was used to extract the rules. The input variables of these algorithms include the number of loan files, customer status of the credit file, age, gender, area, salary, "the ratio of debt to consumed credit","the ratio of profit to consumed credit" and "the ratio of APR to allocated-credits". The model for customer classification using decision tree is shown in Figure 10.

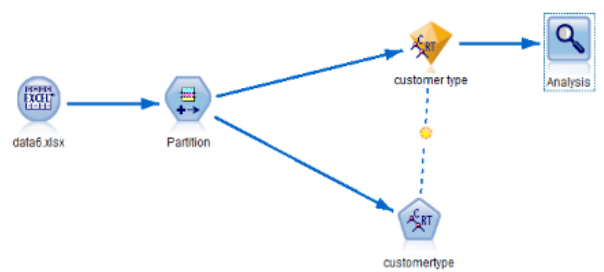

Figure 10. classification model
After the implementation of the model in order to ensure the model accuracy, the model accuracy was examined for the results obtained in the training and test data, which is shown in Table 7.

Table 7. Accuracy of the C\&RT algorithm

\begin{tabular}{|c|c|c|c|c|}
\hline & \multicolumn{2}{|c|}{ Training } & \multicolumn{2}{c|}{ Testing } \\
\hline Correct & 531 & $97.6 \%$ & 371 & $97.9 \%$ \\
\hline Wrong & 13 & $2.4 \%$ & 8 & $2.1 \%$ \\
\hline Total & 544 & $100 \%$ & 379 & $100 \%$ \\
\hline
\end{tabular}

Results show the accuracy of C\&RT algorithm was above $97 \%$ in the training and test data, which indicates the high model accuracy. The results also showed that the variables "amount of debt to consumed credit", "amount of consumer profit to consumed credit" and "debt type" had the highest role in choosing customers with high, medium and low quality, and demographic variables such as region, age and etc are of no significant importance. In Figure 11, the results of the variables importance are displayed. 
Figure 12 and Table 8 refer to the rules extracted from the decision tree for credit card customers.

Some variables have different states and values. For example, the “debt type” variable has three states (No-debt, Non-overdue debt, overdue debt). So we consider a code for each state and value. The codes for each state and value used in the classification model, is shown in Table 9.

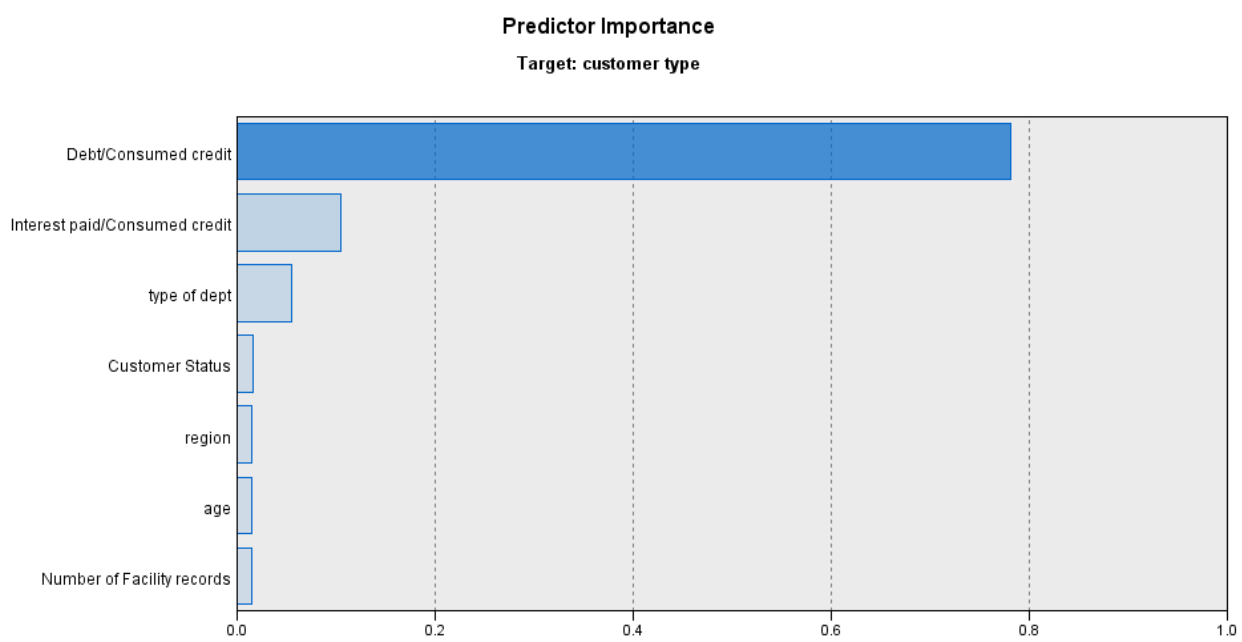

Figure 11.Variables Importance

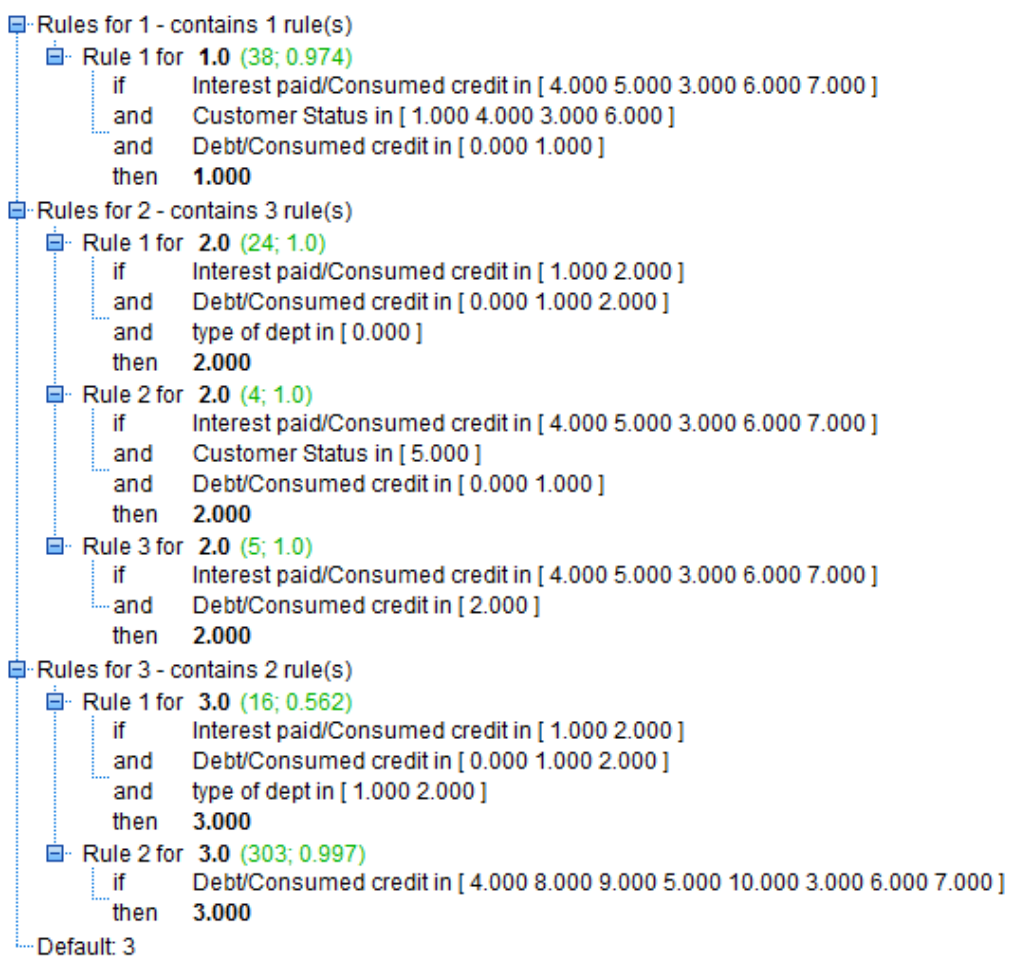

Figure 12. Rules derived from C\&RT 
Table 8. Rules derived from C\&RT

\begin{tabular}{|c|c|c|c|}
\hline $\begin{array}{l}\text { Customer } \\
\text { Class }\end{array}$ & $\begin{array}{l}\text { Rules } \\
\text { Number }\end{array}$ & Rules derived from C\&RT algorithm & Confidence \\
\hline $\begin{array}{l}\text { High-quality } \\
\text { customers }\end{array}$ & Rule 1 & $\begin{array}{l}\text { If Interest paid/Consumed credit in }[4,5,3,6,7] \text { and Customer } \\
\text { Status in }[1,4,3,6] \text { and Debt/Consumed credit in }[0,1] \text { then } \\
1 \text {, }\end{array}$ & $97 \%$ \\
\hline \multirow{3}{*}{$\begin{array}{l}\text { Middle- } \\
\text { quality } \\
\text { customers }\end{array}$} & Rule 2 & $\begin{array}{l}\text { If Interest paid/Consumed credit in }[1,2] \text { and } \\
\text { Debt/Consumed credit in }[0,1,2] \text { and type of debt in [0] then } \\
2\end{array}$ & $100 \%$ \\
\hline & Rule 3 & $\begin{array}{l}\text { If Interest paid/Consumed credit in }[4,5,3,6,7] \text { and Customer } \\
\text { Status in [5] and Debt/Consumed credit in }[0,1] \text { then } 2\end{array}$ & $100 \%$ \\
\hline & Rule 4 & $\begin{array}{l}\text { If Interest paid/Consumed credit in }[4,5,3,6,7] \text { and } \\
\text { Debt/Consumed credit in [2] then } 2\end{array}$ & $100 \%$ \\
\hline \multirow[t]{2}{*}{$\begin{array}{l}\text { Low-quality } \\
\text { customers }\end{array}$} & Rule 5 & $\begin{array}{l}\text { If Interest paid/Consumed credit in }[1,2] \text { and } \\
\text { Debt/Consumed credit in }[0,1,2] \text { and type of debt in }[1,2] \\
\text { then } 3\end{array}$ & $56 \%$ \\
\hline & Rule 6 & If Debt/Consumed credit in $[4,8,9,5,10,3,6,7]$ then 3 & $99 \%$ \\
\hline
\end{tabular}

Table 9. variables Code

\begin{tabular}{|c|c|c|}
\hline Variable name & states and values & Variable code in the model \\
\hline \multirow{8}{*}{ Interest paid/Consumed credit } & 0 & 0 \\
\hline & Between $1 \%$ to $5 \%$ & 1 \\
\hline & Between $6 \%$ to $10 \%$ & 2 \\
\hline & Between $11 \%$ to $15 \%$ & 3 \\
\hline & Between $16 \%$ to $20 \%$ & 4 \\
\hline & Between $21 \%$ to $25 \%$ & 5 \\
\hline & Between $26 \%$ to $30 \%$ & 6 \\
\hline & More than $30 \%$ & 7 \\
\hline \multirow{3}{*}{ Debt Type } & No-debt & 0 \\
\hline & Non-overdue debt & 1 \\
\hline & Overdue debt & 2 \\
\hline \multirow{11}{*}{ Debt/Consumed credit } & 0 & 0 \\
\hline & Between $1 \%$ to $10 \%$ & 1 \\
\hline & Between $11 \%$ to $20 \%$ & 2 \\
\hline & Between $21 \%$ to $30 \%$ & 3 \\
\hline & Between $31 \%$ to $40 \%$ & 4 \\
\hline & Between $41 \%$ to $50 \%$ & 5 \\
\hline & Between $51 \%$ to $60 \%$ & 6 \\
\hline & Between $61 \%$ to $70 \%$ & 7 \\
\hline & Between $71 \%$ to $80 \%$ & 8 \\
\hline & Between $81 \%$ to $90 \%$ & 9 \\
\hline & Equal or More than $30 \%$ & 10 \\
\hline \multirow{6}{*}{ Customer Status } & Closed & 1 \\
\hline & Inactive due to debt & 2 \\
\hline & Inactive & 3 \\
\hline & Active & 4 \\
\hline & Blocked due to debt & 5 \\
\hline & Expired & 6 \\
\hline
\end{tabular}

After identifying 93 quality customers, the information of these customers was investigated in terms of how to use the credit card, how to payout the installments, the number of loan files, allocated credits, and etc. Its results are displayed in Table 10. 
Table 10. customer's credit card information

\begin{tabular}{|c|c|c|c|}
\hline \multicolumn{2}{|c|}{ Variable name } & frequency & percent \\
\hline Fixed Credit & 40 & $43 \%$ \\
\hline \multicolumn{2}{|c|}{ Revolving Credit } & 53 & $57 \%$ \\
\hline \multirow{2}{*}{$: 心$} & $\begin{array}{c}300 \\
\text { million }\end{array}$ & 37 & $40 \%$ \\
\cline { 2 - 3 } & $\begin{array}{c}500 \\
\text { million }\end{array}$ & 56 & $60 \%$ \\
\hline
\end{tabular}

$43 \%$ of "high-quality customers" only had one loan file, which indicates that $43 \%$ individuals have used credit-cards once (loan card) and the revolving credit was not important to them. $57 \%$ of them had more than one loan file (between 2 and 23 cases), which shows that $57 \%$ of customers use revolving credit.

Regarding allocated-credits, $40 \%$ of the customers had allocated-credits of 300 million Rials and $60 \%$ of them had allocated-credits of 500 million Rials and none of them had allocated-credits of 100 million Rials.

Examining the behavior of these customers in using a credit-card during a one-month period showed that $50 \%$ of the loan files were comprised of between 10 and 50 million-Rials, and that the files had the highest rating than other loan files. Therefore, it can be concluded that most of the transactions carried out by these customers over a one-month period ranged from 10 to 50 million Rials, which indicates the use of a credit card in retail purchases. On the other hand, the highest amount of loan files made by the customers was equal to the total of allocated-credits (300/500 million Rials), accounting for $20 \%$ of these customers.

One of the features of credit cards is the flexibility in its payout method, with different time periods (once payout, 3, 6, 12, 18, 24 and 36 months payout). In the sample, it was found that the method of payout of $39 \%$ of customer loan files was 36 months, and this method had the highest rank in comparison with other methods of payout. The method of payout of $27 \%$ of the loan files was payout at once. The high percentage of the once payout is due to 2 reasons. The first reason is the use of creditcards in payments less than 500 thousandtomans because debts installment cannot be paid for less than 500 thousand tomans to the customer and the second reason is the high interest of card holders in choosing the once payment method. On the other hand, the method of payout with 18 month installments had the lowest rank in the sample ( $0.1 \%$ of the loan files).

\section{Conclusions}

This study was conducted to investigate the behaviors of profitable customers of credit card and to find the appropriate model for creating new strategies, introducing new products and improving existing products. So, after collecting data, high-quality customers were selected using data-mining tools (clustering/classification). Thus, from the results obtained from rule. 1 of the C\&RT algorithm (Table 8), 93 high-quality customers were identified, accounting for about $10 \%$ of customers in cluster 2 . The information of these customers was investigated in terms of how to use the credit card, how to payout the installments, the number of loan files, allocated-credits, and etc. The results of the analyses showed that $43 \%$ of high-quality customers use a credit card as the loan card and $57 \%$ of highquality customers use revolving credit of card credit. Moreover, surveys showed that most customers, who use revolving credit cards, used the highest amount of allocated credits during a transaction, and start payout with their maximum installment (36 months). Then, by payout the debt, the credit card is recharged to the exact amount of the installment, and due to the low installment amount, it will only be possible for the customers to use cards in retail payments. Furthermore, given the low transaction cost, there is no possibility of installing debts to customers, which leads to the choice at once payout in many credit files. On the other 
hand, the number of customers who used the credit-card as a loan card (fixed credit) and payout their debt with 36 month installments is significant. Given the above, creating a variety of credit card features and delivering different products will make it more profitable for the bank and bring more customer satisfaction. In order to improve, creating variety in products and higher profitability, the followings were suggested:

1. Providing a product with a fixed credit considering important allocated credits and a 36 month payout method.

2. Providing a product with the revolving credit, a low amount of allocated credits, and considering the number of installments less in the payout method.

In doing so, there were limitations such as lack of access to more sample numbers and the lack of investigating some demographic features of customers such as their education and job. These suggested that future research should be conducted with larger samples and using fuzzy-logic to compare it with this research in terms of accuracy. Also some of the studies conducted in classification are looking for increased accuracy and sensitivity in classification. This study combine fuzzy-methods and optimizationalgorithms such as combining "optimized rough set theory and fuzzy-logic" algorithms (Thippa Reddy \& Khare, 2017b). The results indicate an increased accuracy and sensitivity in classification. Another study on classification was done to decrease the features through locality preserving projection. It showed that decrease in features does not lead to reduce accuracy in classification. Also, a combination of Firefly, BAT and rule-based fuzzy-logic causes to decrease complication and increase accuracy in classification (Thippa Reddy \& Khare, 2017a). Therefore, it is recommended that optimization-algorithms and fuzzy-logic will be used in future studies in order to increase the accuracy to classify credit-card customers.

\section{References:}

Alborzi, M., \& Khanbabaei, M. (2016). Using data mining and neural networks techniques to propose a new hybrid customer behaviour analysis and credit scoring model in banking services based on a developed RFM analysis method. Int.J. Business Information Systems, 23(1), 1-22.

Anabila, P., \& Dadson, A.V. (2013). Customer Relationship Management: A Key to Organisational Survival and Customer Loyalty in Ghana's Banking Industry. International Journal of Marketing Studies, 5(1), 107-117.

Al-Qudah, K., Al-Hawary, S., \& Al-Mehsen, M. (2012). Electronic Credit Cards Usage and Their Impact on Bank's Profitability: The Rate of Return on Owners Equity Model. INTERDISCIPLINARY JOURNAL OF CONTEMPORARY RESEARCH IN BUSINESS, 4(7), 828-841.

Ansari, A., \& Riasi, A. (2016). Taxonomy of marketing strategies using bank customers' clustering. International Journal of Business and Management, 11(7), 106-119.

Baba, B., Zabri Shafie, M., \& Kaseri, A. (2018). Assessing the Influence of Islamic Banks' Products' Quality Features on Customer Satisfaction in Nigeria. Path of Science (Traektoriâ Nauki Path of Science), 4(6), 4001-4015.

Boon-Hui Chai, B., See Tan, P., \& Shong Goh, T. (2016). Banking Services that Influence the Bank Performance. Procedia-Social and Behavioral Sciences, 224, 401- 407. 
Butaru, F., Chen, Q., Clark, B., Das, S., W. Lo, A., \& Siddique, A. (2015). Risk and Risk Management in the Credit Card Industry. Journal of Banking \& Finance, 72, 218-239.

Chocholáková, A., Gabčová, L., Belás, J., \& Sipko, J. (2015). Bank Customers’ Satisfaction, Customers' Loyalty and Additional Purchases of Banking Products and Services. A Case Study from the Czech Republic. Economics and Sociology, 8(3), 82-94.

Doğan, O., Ayçin, E., \& Atıl Bulut, Z. (2018). Customer Segmentation by Using RFM Model and Clustering Methods: A Case Study in Retail Industry. International Journal of Contemporary Economics and Administrative Sciences, 8(1), 1-19.

Eklofa, J., Podkorytova, O., \& Malova, A. (2018). Linking customer satisfaction with financial performance: an empirical study of Scandinavian banks. Total Quality Management, 1-20, DOI: 10.1080/14783363.2018.1504621.

Farokhi, S., Teimourpour, B., Shekarriz, F., \& Masoudi, M. (2016). A new application of clustering for segmentation of banks' e-payment services based on profitability. Uncertain Supply Chain Management, 4(1), 55-60.

Farooqi, R., \& Iqbal, N. (2017). Effectiveness of Data mining in Banking Industry: An empirical study. International Journal of Advanced Research in Computer Science, 8(5), 827-830.

Fouladifar, A., Taghipour, E., \& Hedayati, A. (2016). Market Segmentation for Marketing of Banking Industry Products Constructing a Clustering Model for Bank Pasargad's E-Banking Customers Using RFM Technique and K-Means Algorithm. International Business Management, 10(6), 1106-1119.

Garvey Orji, M., Andah, R., Chima, K., \& Solomon Boman, A. (2017). Impact of New Products Development on the Profitability of Nigerian Deposit Money Banks. International Journal of Economics, Finance and Management Sciences, 5(4), 213-221.

He, Y., Wang, L., He, Z., \& Xie, M. (2016). A fuzzy TOPSIS and rough set based approach for mechanism analysis of product infant failure. Engineering Applications of Artificial Intelligence, 47, 25-37.

Hua, Z., Zhang, X., \& Xu, X. (2011). Product design strategies in a manufacturer-retailer distribution channel. Omega, 30(1), 23-32.

Keisidou, E., Sarigiannidis, L., Maditinos, D.I., \& Thalassinos, E.I. (2013). Customer satisfaction, loyalty and financial performance: A holistic approach of the Greek banking sector. International Journal of Bank Marketing, 31(4), 259-288.

Khajvand, M., \& Tarokh, M.J. (2011). Estimating customer future value of different customer segments based on adapted RFM model in retail banking context. Procedia Computer Science, 3, 1327-1332.

Khansari, R. (2016). Opportunities and Challenges of International Credit-Card in Iranian Banking System. Monetary and Banking Institute of the Central Bank of the Islamic Republic of Iran.

Kraniasa, A., \& Bourlessa, M. (2013). Investigating the Relationship Between Service Quality and Loyalty in Greek Banking Sector. Procedia Economics and Finance, 5, 453-458.

Kumar, M.V., Chaitanya, M.V., \& Madhavan, M. (2012). Segmenting the banking market strategy by clustering. International Journal of Computer Applications, 45(17), 10-15.

Ladhari, R. (2010). Developing e-service quality scales: A literature review. Journal of Retailing and Consumer Services, 17, 464-477. 
Liu, C., \& Wang, T. (2017). A study on the effect of service quality on customer loyalty and corporate performance in financial industry. Problems and Perspectives in Management, 15(2), 355-363.

Liébana-Cabanillas, F., Nogueras, R., Herrera, L.J., \& Guillén, A. (2013). Analysing user trust in electronic banking using data mining methods. Expert Systems with Applications, 40(14), 5439-5447.

Munawar Khan, M. (2014). Impact of Service Quality on Customer Satisfaction and Customer Loyalty: Evidence from Banking Sector. Pakistan Journal of Commerce and Social Sciences, 8(2), 331- 354.

Rousseeuw, P.J. (1987). Silhouettes: A graphical aid to the interpretation and validation of cluster analysis. Journal of Computational and Applied Mathematics, 20, 53-65.

Thippa Reddy, G., \& Khare, N. (2017a). An Efficient System for Heart Disease Prediction using Hybrid OFBAT with Rule-Based Fuzzy Logic Model. Journal of Circuits, Systems, and Computers, 26(4), 21.

Thippa Reddy, G., \& Khare, N. (2017b). Cuckoo Search Optimized Reduction and Fuzzy Logic Classifier for Heart Disease and Diabetes Prediction. International Journal of Fuzzy System Applications, 6(2).

Valdés, G., Mauricio, S., Astudillo, H., Iribarren, M., Concha, G., \& Visconti, M. (2011). Conception, development and implementation of an e-Government maturity model in public agencies. Government Information Quarterly, 28(2), 176-187.

Xu, J., Sun, K., \& Xu, L. (2016). Integrated system health management-oriented maintenance decision making for multi-state system based on data mining. International Journal of Systems Science, 47, 3287-3301.

\section{Ladan Hassani}

PHD Student, Islamic Azad University, Science and Research Branch,

Faculty of Management and Economics,

Tehran

Iran

l.time.h5@gmail.com

\section{Ehsan Taati}

M.Sc. Shahid Beheshti

University, Information

Technology Management

Department, Faculty of

Management and

Accounting,

Tehran,

Iran

Eh.taati@gmail.com 


\section{Appendix:}

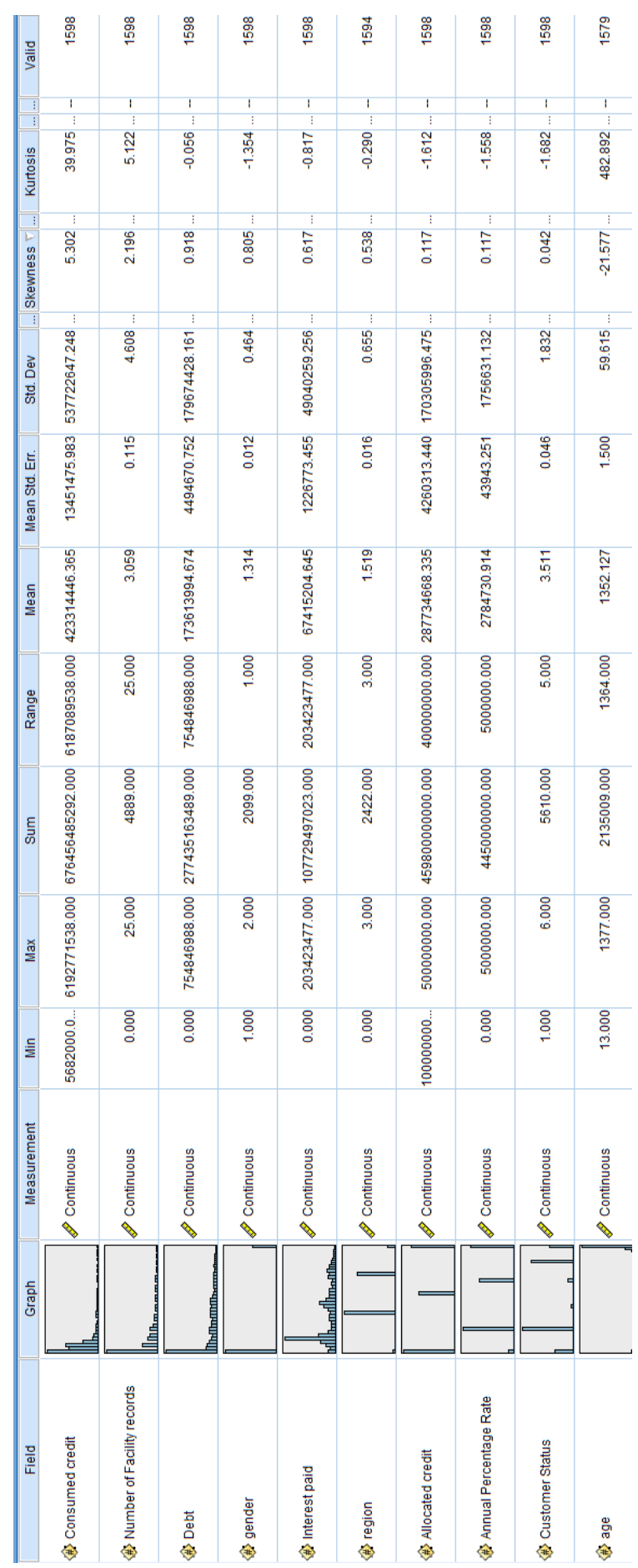

Figure 4. Primary Data Statistics 


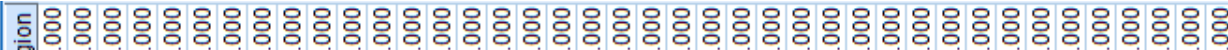
ด

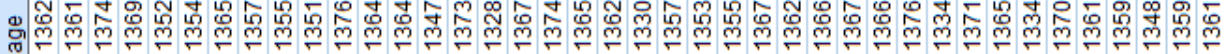

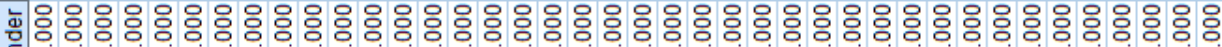

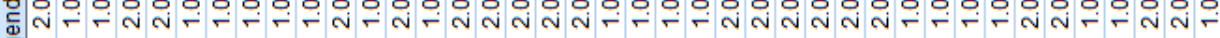

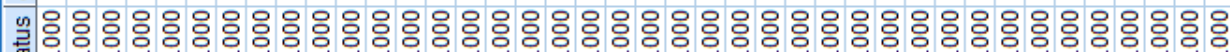
署

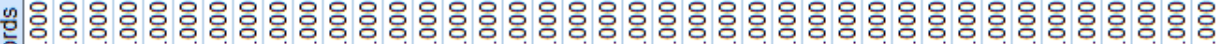
ó:

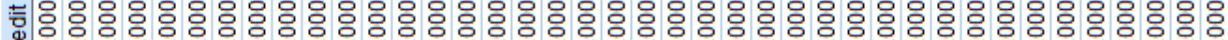
๘

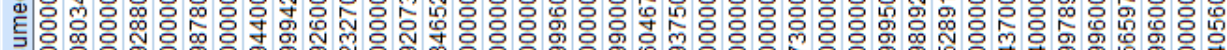

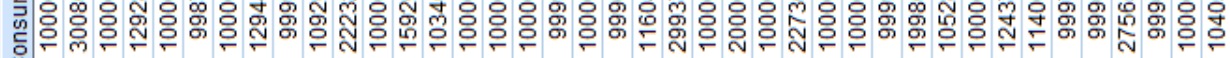

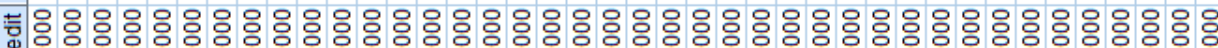
ㄴㅇㅇㅇㅇㅇㅇㅇㅇㅇㅇㅇㅇㅇㅇㅇㅇㅇㅇㅇㅇㅇㅇㅇㅇㅇㅇㅇㅇㅇㅇㅇㅇㅇㅇㅇㅇㅇㅇㅇㅇㅇㅇㅇ

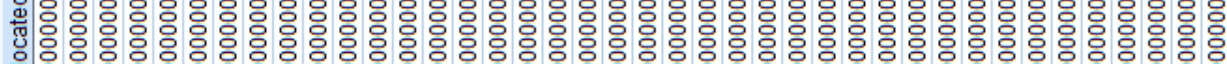

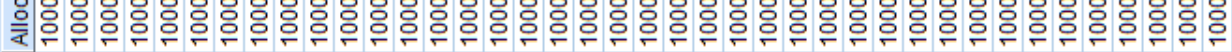

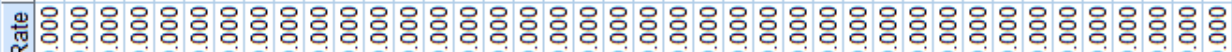

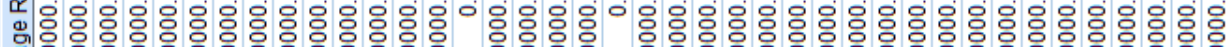

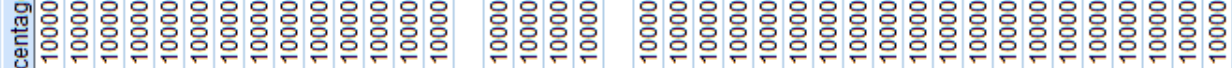

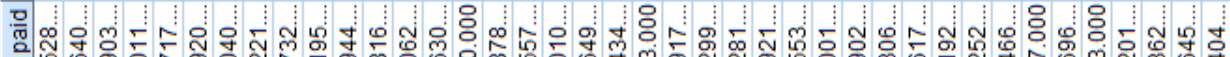

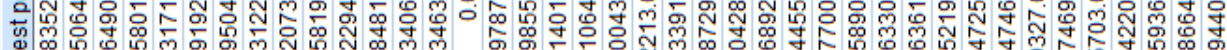

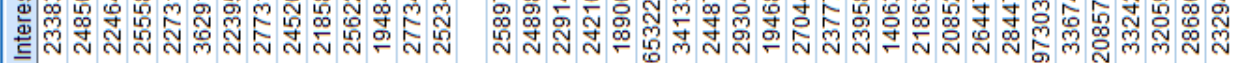

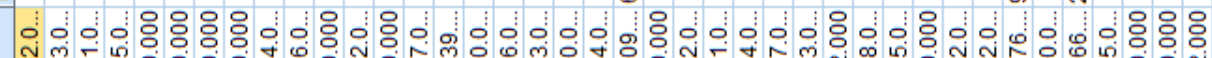

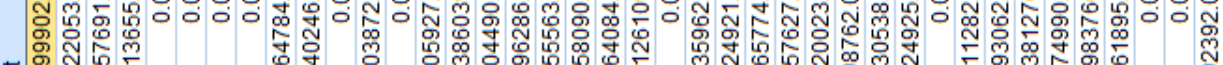

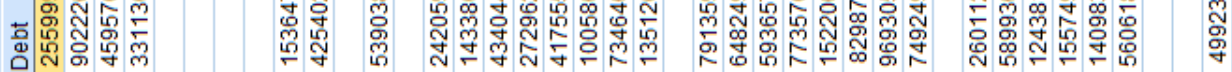

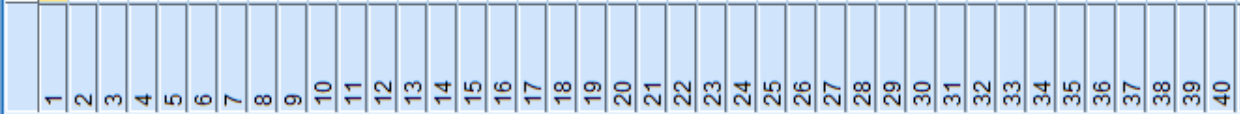

Figure 5. Preprocessed data overview 


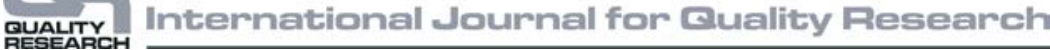

